\title{
African Quest for Development and Chinese Strategic Policy in the Continent: Myth or Reality in a Developmental Path in the $21^{\text {st }}$ Century
}

\author{
Victor Ojakorotu* and Fie David Dan-Woniowei
}

\author{
Department of Politics and International Relations, North West University, Mafikeng, South Africa
}

\begin{abstract}
Bilateral or multilateral relationships among nations or regional blocs are changing rapidly. For instance, Chinese interest in Africa, which began since the early part of the 21 st Century, have assumed incredible dimensions. Since then, the growing Chinese footprints in Africa have orchestrated various debates within the academia and public policy experts, describing their relationship as a "major geopolitical feature" in this era of a globalised world. A situation that calls for understanding of the nature of their relationship with a view of creating an integrated African policy framework to tackle perceived negative trends of Chinese role in the Continent vis-à-vis the developmental challenges of African States. Such views have been quite diverse and contentious over the years. Quite a number of views suggests that China's new relationship with the Continent is a substitute to Western relationship that can offer the needed partnership for the most needed economic growth and infrastructural development of African States. This position informed the initiative called the Forum on China-Africa Cooperation (FOCAC) in the year 2000, and its subsequent formation in 2010 with the ultimate objective of implementing both political and economic programmes in Africa (Stahl, 2016). Available records show that China have implemented two coherent policies on Africa between 2006 and 2015. Against this backdrop, came the warnings of some scholars as well as States to African States to be wary of such Chinese benevolence. The West championed by Washington and Brussels were among such active voices.

From the two extreme viewpoints, lies the desire of this paper to analyse holistically, Chinese strategic policy outcomes vis-à-vis the African development needs from 2014 to date. The intention is to contribute to the ongoing debate about Africa-China relations vis-à-vis the development needs of the Continent. Such holistic analytical approach will further expose the potential impact of the Chinese strategic policy outcomes and the extent of development of African States. Interestingly, the paper will be able to throw open to African States of the choice to doing business with whomever they like based on their development challenges or needs per time and not because of colonial ties or linkages.
\end{abstract}

Keywords: Development, Strategic policy, Myth or reality.

\section{INTRODUCTION}

The bilateral or multilateral relations between China and Africa have grown rapidly and have assumed incredible dimensions in the $21^{\text {st }}$ century (Stahl, 2016). Some analysts have described the trend as a "major geopolitical feature" in this era. African countries have in the past viewed China on a trajectory of anti-colonial struggles but in recent years, have come to terms with China as a viable partner to resolve African development challenges (Hodzi et al. 2012; Berhe and Hongwu, 2013). However, this newfound relationship has created divergent views and concerns (Sun, 2014). For example, Igbinoba (2016) sees Africa's relationship with China now as an opportunity for the Continent "to substitute western relationship and a conveyor of economic growth" and/or development. Earlier, Huse and Muyakwa (2008) asserts that the China-Africa relationship is due largely by limited transparency of high-stake negotiations on trade and investments in aids. Such views underscore the fact that Chinese policy on trade, foreign investment have no strings

*Address correspondence to this author at the Department of Politics and International Relations, North West University, Mafikeng, South Africa; Tel: 018 3892259, 078 3756718; E-mail: vojakoro@yahoo.com attached (Condon, 2012), which makes it more manageable and user friendly by African countries. It also relies on the notion that Chinese aid unlike western aid does not infringe on a country's sovereignty or meddle in its internal affairs (Carmody, Dublin and Taylor, 2009). Furthermore, the principle upon which China and Africa relates is its "no questions asked policy" (Carmody, Dublin and Taylor, 2009) regarding the terms and conditions of development lending, viewed favourably by African leaders as keen to maximise self-determination and minimise non-tariff trade barriers. Relying on such view, the Bank Information Centre (BIC) (2006) argues that Chinese benevolence may have the effect of loosening social and environmental safeguards when African countries continue to look on China for its development needs. In other words, the high-stake collaborative statebusiness approach to foreign policy favours Chinese firms to bear the risks that hinder investment by other players and would definitely have some harm on the growth of local industries (Edinger, 2008).

The above complexes surrounding academic discourses and public policy fora calls for further scrutiny. In particular, the increasing Chinese role and/or strategic national interest as a policy thrust 
towards Africa's developmental challenges should be of great concern. Hence, this article focuses on the complex China-Africa strategic policy outcomes involving trade and investments, aid or loans, and security cooperation on the Continent. The article evaluates the China-Africa policy outcomes on the Continent by adopting the critical analytical framework in order to create further understanding of Chinese major policy strands and engagements, as well as to expose if their relationship is beneficial to the Continent or not. To achieve this, few flashpoints of China-Africa cooperation in three African countries such as Nigeria, Zimbabwe and South Africa is on the radar. This enables us to suggest a country-by-country policy approach to African nations in its engagements with China. That China's single Africa policy framework in dealing with African countries as a means to tackling their developmental challenges is a misnomer. The country-by-country framework provides further grounds to African States in relating with all development partners including its Western allies in tackling Africa's development needs devoid of colonial affiliation, conditionality or sanctions and gimmicks.

\section{OVERVIEW OF CHINA-AFRICA STRATEGIC POLICY}

The strategic engagements between China and Africa have multiple strands. For instance, Stahl (2016) describes its complex nature as "pluralisation" in recent years. According to Ajakaiye (2006), the most crucial aspect of it started when China re-enacted its long tradition of China-Africa friendship towards the Continent dubbed, "China-Africa Policy" on January 2006. The so-called China-Africa policy aims at enhancing African solidarity in the arena of global politics and economic cooperation with the Peoples Republic of China. Evidently, China's primary interest in Africa is for its "economic prospects in terms of natural resources, trade and investments" (Stahl, 2016), which have been "broadened over the past years to include diplomatic, security and cultural cooperation" (Stahl, 2016). Ajakaiye (2006), had earlier indicated that in Part IV of the 2006 China-Africa policy document, China had articulated its strategy for engaging with Africa in the political field; economic field; education, science, culture, health and social field; and peace and security field. The 2015 ChinaAfrica policy framework further encapsulates China's momentum for a more coherent strategic policy in engaging with the 54 African countries on a mutual and more beneficial way to achieve its foreign policy objectives in relation to African development needs
(Berhe and Hongwu, 2013). From Berhe and Hongwu (2013)'s view, we can deduce that the underlying principle of the "one China policy" is for China to achieve its foreign policy objectives at the expense of Africa's developmental challenges.

Nevertheless, Igbinoba (2016) is of the view that the policy although have its inherent criticisms, African countries are treated better by China than their Western development partners "who treat different African countries with different policies and objectives". Stahl (2016) also acknowledges that China's foreign policy currently covers almost the whole of the African continent and does not make any distinction between particular regions. By this policy, China have "maintains diplomatic relations with all 54 recognised countries on the Continent" (Stahl, 2016), except for three States "Burkina Faso, São Tomé and Príncipe, and Swaziland", which "maintain official diplomatic relations with Taiwan" (Stahl, 2016). Gambia have also decided to resume diplomatic relations with China at the expense of Taiwan in March 2016 (Stahl, 2016). In all intents and purposes, China viewing Africa as a single political and economic entity is divisive. This is for the fact that African countries have diverse developmental realities and priorities even though many may perceive that Africa has a shared colonial history. This has made it very difficult for African collective bargain and resolution on strategic policy issues involving trade and investment, security among others. The onus lies on every individual African country to consider its developmental priorities into transparent strategic policies while engaging China on its single policy framework.

Certainly, Africa have strong links with China's national interests. A situation which have made many analysts to place the Continent now as part of Chinese international relations and foreign policy calibration. China have strategic diplomatic engagements with African countries on the political, economic, security and cultural fronts through the FOCAC partnership framework. Through FOCAC, China have put forward a roadmap called, "the FOCAC VI Action Plan 2016 2018 and China's second Africa Policy" as complementary strategy to Agenda 2063 to realise its foreign policy goals in Africa. China's broad strategic foreign policy goals, (i.e. economic goals fashioned and/or implemented mainly as trade and investments deals, security and cultural cooperation agreements, etc.), are underpinned by a 'steadfast' non-interference diplomatic policy. The non-interference diplomatic policy of China provides a veritable alternative to 
Western power models of trade and investment, which conditionally bonds African countries to issues of good governance and other forms of sanctions. Africa is therefore an important ground for Chinese businesses and other forms of economic activities.

\section{CHINA-AFRICA STRATEGIC DIPLOMATIC POLICY OUTCOMES}

The Chinese strategic foreign policy goals embedded as political and economic goals are fashioned, vigorously pursued and implemented through FOCAC in Africa. Let us examine each of these strategic policy goals and potential outcomes in the China-Africa cooperation.

\section{FOCAC Engagements}

The Forum on China-Africa Cooperation (FOCAC) is the main diplomatic instrument by which China strategically engage Africa to achieve its strategic political and economic goals in Africa. The idea for its formation was first conceived in the year 2000 and its subsequent establishment was in 2010 (Stahl, 2016; German et al. 2011). The Forum functions as a major politico-institutional machinery for promoting political dialogue and economic cooperation (strengthen diplomatic relations) between China and Africa (Stahl, 2016; Berhe and Hongwu, 2013; German et al. 2011). In other words, the Forum's ultimate desire is for China to ensure the implementation of political and economic (cultural) programmes in Africa. Evidently, in FOCAC, China does not only seek to enhance economic ties with the Continent, it also strengthens and deepen political and/or diplomatic relations with African countries. Strategically, China views the Continent 'as a single political entity' and as 'an arena in which to grow and exert its international influence'. The truth is that many African governments embraced FOCAC, however, 'there remains no clear strategy and coherent African policy on China to guide Africa's engagement; neither do most African governments have policies regulating their bilateral relations with China' (Hodzi et al. 2012). A condition that have enabled China to determine singly its relationship with Africa.

Undoubtedly, China-Africa relations have assumed incredible dimensions as it now provides some form of opportunity to African countries to stimulate economic growth and development in terms of construction of new infrastructures and rehabilitation of aging ones. Hodzi et al. (2012) states that Chinese foreign aids focus on infrastructure development such as transportation and telecommunication in order to reduce the cost of trade, thereby creating a more competitive environment for African businesses, creating employment and increasing demand for goods. Therefore, such key components of economic cooperation between China and Africa is strategic. As a result, China may continue to play defining role in most African national (unstable or weak) economies (German et al. 2011). Therefore, among the critical questions surrounding the academia, policy experts and traditional development partners are, will such Chinese strategic role and/or benevolence not going to undermine the long-term development efforts of African countries? Alternatively, will it not increase the indebtedness and competition of local industries? Will it not also slow down the advances made in governance (German, et al. 2011)? Let us provide some plausible answers to these very critical questions while assessing the strategic policy outcomes in each sphere of influence in the following sections.

\section{Economic Engagements}

Berhe and Hongwu (2013) pointed out that over the past decade, Chinese economic engagements with Africa significantly increased with the institutionalisation of its economic policies strategically in FOCAC and publication of White Papers on the China-Africa Policy in 2006, as well as the China's Foreign Aid programme in 2011. Scholarly discusses and policy experts' debates have seen Chinese strategic economic policy on Africa as a competitor and/or veritable alternative to the US and EU on African development challenges (Igbinoba, 2016). Let us examine the economic policy with specific spheres of influence.

\section{i. In the Sphere of Trade and Investment}

Rich (2007) indicated that China is the third largest trading partner in the world in the past few decades. According to the study, the trade between China and Africa exploded as demand for imports risen to fuel the rapidly expanding manufacturing sector. Asche and Schüller (2008) and the World Investment Report (2013) also acknowledges that China is a significant source of foreign direct investment (FDI) and development lending, with investment by state-owned and private commodity corporations rising rapidly due to government support programmes. Viewed critically, the Sino-African trade and investment cooperation concentrates more on resource-rich African economies. Kolstad and Wiig (2011) in this wise, have reported that Chinese national oil companies have major resource investments in Angola, Sudan, Nigeria, Equatorial Guinea, and Kenya. In addition, in the sphere of FDI, 
Asiedu (2006) reported that China have robustly make available FDI to most African countries on the basis of resource endowments, market potential and good institutions. Major African countries in this category of Chinese FDI stock are South Africa, Sudan, Nigeria, and Zambia. The outcome is a new symbiosis built around resources availability and market potentials of Chinese manufactured goods. In other words, China's demand for raw materials responding to Africa's relatively abundant supply of energy, minerals, timber and land, and the growing demand in Africa for Chinese manufactured goods. The robust economic relations of China and Africa grew tremendously even during the recent global financial crisis, a period even many companies scaled back operations.

Chinese investments in Africa are important sources of capital for a number of African countries. The high volume of trade and investment between China and Africa in timber, agricultural cash crops and biofuels, as well in the areas of infrastructure (railways, roads, telecommunication) and facility construction projects (government buildings, stadiums, hospitals, schools) (Biggeri and Sanfilippo, 2009) have facilitated economic growth and infrastructure development in most African countries. However, such infrastructure development needs of African countries, which informed the so-called Chinese strategic 'unconditional aid' policy in Africa is another case in point. The strategic aid policy of China (designed around development projects), is premised on the notion that it could reduce the cost of trade and create a more conducive and competitive African business environment, as well as creating employment and increasing demand for manufactured goods. This is a state-centric view, as unfolding events now in the Continent about China speaks contrary to the claim. For instance, China instead of channelling money to the recipient country's banks which sometimes presumably ends up in the ruling elite's bank accounts, China tends to avoid this by contracting Chinese firms who themselves implement the projects (Hodzi et al. 2012). Canby et al. (2007), Milledge et al. (2007), German et al. (2010), Mandondo and German (2011), have all asserted that such activities of China are already creating environmental sustainability concerns. In this regard, (Asche and Schuller 2008) have reported that Chinese firms have been criticised for violations of anticorruption, environmental, labour and social standards in Africa, which are also raising concerns about the sustainability of extractive activities (de Wit 2007). Therefore, Rotberg (2008) have asserted that the new-found Africa-China symbiosis could be a veritable opportunity in 'the making of Africa' by creating jobs, export processing zones and investments in education and infrastructure, but it could undermine long-term development via imported labour, competition with African goods, resource depletion and by slowing advances in governance in Africa.

The quality of trade between Africa and China will thus remain an important feature to observe as the relationship continues to mature. Let us assess few flashpoints of China-Africa economic and diplomatic engagements in three key African countries.

\section{(a) Nigeria}

According to Igbinoba (2016), trade between Nigeria and China has over the last two decades grown from a period of restrictive and periodic association to an era of increasingly complicated and expansive interrelationship. The study also indicated that the trade volume between the two countries increased from 1.2 billion Naira in 1998 to 11.4 billion US dollar in 2011, making Nigeria Africa's second largest trading partner. Furthermore, the study pointed out that of the 11.4 billion US dollar, 10 billion US dollar was the total value of Nigeria import while total export totalled 1.4 billion US dollar. Additionally, natural resources depict approximately $90 \%$ of Africa's export to China with Zambia, The Congo, Angola, South Africa and Ghana as major exporters. The trend shown over the years indicated that there has been a growing structural imbalance in trade between Nigeria and China as well as between China and other African countries.

The Nigerian situation in Africa explains that trade relations between China and Africa mainly is on exports of raw materials at cheaper prices and imports of finished goods at a heavier cost. A trade, which benefitted mostly China in flooding African markets with cheap goods from low labour cost and a manipulated currency (Igbinoba, 2016). The dilemma of this kind of Chinese commerce is that African local industries and workforce, and small business owners (especially in the manufacturing and retail sectors) are subtly, relegated to the background. The situation was ones described by Stewart Jennings, Chief Executive of PG Group as "China exporting unemployment to Africa" (Igbinoba, 2016). Therefore, the call from Sanusi Lamido, Nigeria's former Central Bank Governor to African countries to "wake up from their romance with China" (Igbinoba, 2016) may be relevant.

\section{(b) Zimbabwe}

The relationship between Zimbabwe and China has evolved over time, with the key turning point being the 
year 2000 (Ojakorotu and Kamidza, 2018). Prior to 2000, Zimbabwe and China had close political relations underscored in part by China's support to Zimbabwe during its liberation struggle, but these did not translate into "greater economic cooperation". However, from 2003 when Zimbabwe adopted its "Look East" policy, bilateral ties between Zimbabwe and China especially at the economic sphere reached a phenomenal height (Ojakorotu and Kamidza, 2018). Through the "Look East" policy, China has not only supported Zimbabwe economically, in terms of trade and financial investment, but politically as well. Its solidarity in multilateral forums and support for regional initiatives to ensure Zimbabwe's sovereignty are germane. China was able to use its veto power in the United Nations Security Council to shield the Zimbabwean government from potential UN imposed sanctions in 2008.

Additionally, Chinese investments have kept Zimbabwe's economy afloat at a time when it was in a dire state. Chinese investments in Zimbabwe helped to sustain the country's ailing economic development needs, including support to the ailing manufacturing sectors, stimulation of the broad commercial services, development of decaying infrastructure, as well as driving the overall economic sector growth. Nevertheless, the over bearing influence of China in the domestic political and economic landscape of Zimbabwe is increasingly critical.

\section{(c) South Africa}

South Africa is arguably China's most important strategic partner in Africa. The two have close diplomatic and economic ties in order to further deepening China-Africa cooperation. In other words, China feels that South Africa's tacit leadership role in the SDDC region as well as the broader Continental level will engender a new model of China-Africa cooperation. Additionally, South Africa's collaboration with China will facilitate and enhance greater regional development and economic integration of Africa. Policy wise, the interest of South Africa is that China should focus on bilateral agreements, covering key sectoral programmes that would facilitate broader regional development.

Accordingly, China-South Africa partnership has covered various sectors including industrialization, promotion of special economic zones (SEZs) and blue economy, infrastructure and human resources development initiatives, as well as other cultural exchange programmes.
The bilateral framework between China and South Africa have found greater success of interactions among many African models. Thus, the Chinese government have expressed in international forum to model its interaction with Africa according to the South African model of interaction. The China and South Africa model seems succeeding presently because of a strong economic and industrial foundation, which both countries display as vital areas of competence with informed priorities as the basis of their interactions. However, considering at a wider Africa policy level, the China-South African model further underscores the point that the China 'one policy' African framework is not a veritable alternative to African development challenges.

\section{ii. In the Sphere of Chinese Policy Banks}

Stahl (2016) indicated that Chinese policy banks are key players in China's involvement in Africa. The two most important Chinese policy banks involved in the process include the China Export-Import (Exim) Bank and the China Development Bank (CDB) (Stahl, 2016). These banks implement state policies to promote China's trade, investment and industrial activities abroad (Stahl, 2016, Kamal and Gallagher, 2016). According to Stahl (2016), "whereas the CDB plays an important role in funding large infrastructure projects in China and abroad, it is China's Exim Bank that plays a predominant role in supporting China's foreign trade and economic cooperation with Africa". The Exim Bank administers concessional loans according to China's diplomatic and business objectives, and it plays a "policy oriented 'development financing' role" in Africa (Stahl, 2016, Corkin, 2011). The major policy outcome of such a strategic economic (bank/business) policy of China in Africa is that African infrastructural development financing and implementation by Chinese companies would certainly fail because they "to support the activities of Chinese firms" (Stahl, 2016).

\section{iii. In the Sphere of State-owned Enterprises}

State-owned enterprises (SOEs) also plays a significant role in Chinese economic engagements with African countries. According to Stahl, (2016), "most of the Chinese firms operating in Africa are SOEs rather than private-sector firms". Why had China modelled its economic dealings with Africa in this way? The answer is that "since SOEs do not have to face pressures from stockholders as private companies do, they are better suited specifically to advancing the government's broader geopolitical objectives" (Stahl, 2016, Kobayashi, 2008). In line with this economic policy 
goal, Chinese subnational governments also play key role, they establish firms and send them to the Continent under the guise of private entities and take part in providing solutions to African development Challenges. Due to such undercover engagements, China in past have been accused of involving in most of the resources related conflicts in most African States.

\section{iv. In the Sphere of Loans}

Chinese government also reinforces development of African Small and Medium Enterprises (SMEs) by having special loan agreements with African countries. These development agreements mostly focus on the development of infrastructure such as the Addis Ababa to Djibouti, Mombasa to Nairobi, and Abuja to Kaduna railways, and developing special economic zones (SEZs). Undoubtedly, the loans are to facilitate key infrastructural development and to generate employment in the relating African countries. However, the situation with most of them now is that the loans have become huge financial burden and China have started taken over most of the valuable assets such as airports, seaports, mines among others in some Africa countries.

\section{Security Engagements}

Besides business and development related engagements, China also cooperation with Africa in the security arena. This is coming as result of the fact that Africa have the greatest share of most of the conflicts of the world (Stahl, 2016, SIPRI, 2015). The Chinese underlying principle of engagement with Africa include sovereignty and non-interference in the domestic affairs of nations, however, Beijing has become increasingly entangled in the domestic affairs of African nations (e.g. in conflicts) as its economic interests deepens in the Continent (Stahl, 2016, 2011). In recent years, China have faced several security challenges in African countries including Nigeria and Sudan. In these countries, there has been attacks on Chinese oil facilities and kidnapping of Chinese workers by rebels and militia groups (Stahl, 2016, 2011). Additionally, Chinese SOEs have also experienced security risks in Angola and Eastern Congo (Stahl, 2016).

Consequently, China standing on its policy of selfdefence and the ravaging security challenges in Africa put up security policy to enhance the security architecture for the protection of its economic interests in the Continent (Sun, 2014). In other words, African countries are bedevilled with security challenges and its business climate is too fragile to enable large investments to survive. Therefore, the promotion of security in Africa and the survival of Chinese businesses and economic interests is crucial to China in the Continent. The significant outcome of this security policy is the establishment of the Chinese naval base in Djibouti. Strategically argued, the military will carry out regular patrols to ports, thereby would secure the Gulf of Aden, which has seen a rise in piracy since 2011. This is nothing other than a show of force through gunboat diplomacy to protect Chinese business interests and competition with Western powers.

Another outcome of the Chinese military security architecture in Africa is that it has exacerbated the proliferation of arms in the Continent in various respect (Stahl, 2016, Curtis and Hickson, 2006). For instance, Chinese government has accused of arms deals with some African countries including Angola, Botswana, Eritrea, Namibia and Sierra Leone for the supply of military equipment often in exchange for natural resources in the past (Stahl, 2016, Niquet, 2006). Furtherance to this is that these Chinese arms trades tend to be characterised by poor transparency and they frequently bypass United Nations (UN) arms embargos (Stahl, 2016, Curtis and Hickson, 2006). This further stem some experts' argument that China explicitly supports rebel groups and so-called pariah States that are boycotted by the West on human rights grounds, such as Sudan or Zimbabwe (Stahl, 2016, KleineAhlbrandt and Small, 2008).

Nevertheless, China increased its contribution to UN peacekeeping operations (PKOs) and has become the largest contributor to all of the permanent members of the UN Security Council (Stahl, 2016). According to Murray, (2013), China's recent contributions to the UN PKOs is around 1,500 , which is 15 times more than previous contributions from the last 10 years (Stahl, 2016). Stahl (2016) also indicated that the Chinese military has facilitated the logistics space for Africa by helping the UN to carry out counter-piracy missions, particularly in Somalia and the Gulf of Aden. This form of high-level multilateral and/or institutional consultations under the auspices of the UN and African Union (AU) enabled China to establish its military presence in the Continent. The interesting question here is that, where is Africa's security in the context of China and the West?

\section{CONCLUSION}

China-Africa engagements both at bilateral and multilateral levels have reached incredible dimensions 
in recent years. The study affirms that China and Africa new areas of cooperation reached sustainable height when moves for the establishment of the FOCAC instrument gained momentum from the year 2000 (Tjønneland et al. 2006). The Forum since its establishment in 2010 has reinforced China-Africa diplomatic relations in different fields including the international political arena (solidarity at global or regional forums), economic cooperation in the spheres of trade and investments, loans for infrastructure development, as well as security cooperation and cultural exchange programmes with the sole aim of resolving Africa's development challenges. The study agrees to the fact that African countries embraces the robust Chinese benevolence as a veritable opportunity to Western anti-development partnership programmes in trade and investment deals and loans that are usually with strings of conditionality or sanctions. Furthermore, the study argues that the 'one China' policy and its 'non-interference' paradigm triggered China-Africa relationships. However, looking through the lens of China's strategic foreign policy engagements and outcomes, the study opines that the China 'one Africa' policy (China's integrated economic and political development model for Africa and other developing countries) is not a genuine alternative to the development of Africa. That the policy is a ploy by China to satisfy its rising domestic sector needs with Africa's natural resources (Brant, 2013, Tjønneland et al. 2006). For Africa cannot achieve integrated development at the expense of individual national development priorities. The study suggests that African countries should instead of colonial ties, patronage and disguised imperatives, engage development partners based on competence and choice of development priorities.

\section{REFERENCES}

Ajakaiye, O. (2006), "China and Africa - Opportunities and Challenges", A Presentation at the African Union Task Force on Strategic Partnership Between Africa and the Emerging Countries of the South Addis Ababa, Ethiopia 11-13 September: 1-14.

Asche H. and Schüller, M. (2008) China's Engagement in Africa: Opportunities and Risks for Development, Eschborn, Gesellschaft für Technische Zusammenarbeit (GTZ), September, http://s3.amazonaws.com/zanran_storage/ www2.gtz.de/ ContentPages/19176160.

Asiedu, E. (2006) 'Foreign Direct Investment in Africa: The Role of Natural Resources, Market Size, Government Policy, Institutions and Political Instability', World Economy, 29 (1): 63-77. https://doi.org/10.1111/j.1467-9701.2006.00758.x

Bank Information Centre (BIC) (2006), "EIB urges Looser Environmental and Social Standards for Loans to Africa", 7 December. http://www.bicusa. org/en/Article.3037.aspx (15 December 2011).
Berhe, M. and L. Hongwu (2013), "China-Africa Relations: Governance, Peace and Security", Institute for Peace and Security Studies (Addis Ababa University) and Institute of African Studies (Zhejiang Normal University).

Biggeri, M. and M. Sanfilippo (2009) 'Understanding China's Move into Africa: An Empirical Analysis', Journal of Chinese Economic and Business Studies, 7 (1): 31-54. https://doi.org/10.1080/14765280802604714

Brant, P. (2013), "Chinese Aid in the South Pacific: Linked to Resources? Asian Studies Review, 37 (2): 158-177. https://doi.org/10.1080/10357823.2013.767311

Canby, K., J. Hewitt, L. Bailey, E. Katsigris and S. Xiufang (2007), "Forest Products Trade between China and Africa: An Analysis of Imports and Exports", Forest Trends and Global Timber, Washington, DC.

Carmody, P., T. C. Durblin and A. Taylor (2009), "Flexigemony and Force in China's Geoeconomic Strategy in Africa: Sudan and Zambia Compared", Institute for International Integration Studies, IIIS Discussion Paper No. 277, University of St. Andrews, 1-24.

China-Africa: High Time for a Common Integrated Policy on China, Proceedings Report of a Symposium held by the Institute for Global Dialogue (IGD) associated with UNISA, Africa-China Reporting Project (ACRP), and Friedrich Ebert Stiftung (FES) 20th July 2017, Johannesburg.

Condon, M. (2012), "China in Africa: What the Policy of Nonintervention Adds to the Western Development Dilemma", PRAXIS The Fletcher Journal of Human Security, XXVII, 5-25.

Corkin, L. (2011), "Redefining Foreign Policy Impulses toward Africa: The Roles of the MFA, the MOFCOM and China Exim Bank", in Journal of Current Chinese Affairs, 40 (4): 61-90, http://journals.sub.uni-hamburg.de/giga/jcca/ article/view/480.

Curtis, M. and Hickson, C. (2006), "Arming and Alarming? Arms Exports, Peace and Security", In Leni Wild and David Mepham (eds.), The New Sinosphere. China in Africa, London, Institute for Public Policy Research: 37-46, http://www.ippr.org/publications/the-new-sinospherechina-inafrica.

de Wit, M. (2007), "Doing Deals that Last. The China Monitor", 16: 46.

Edinger, H. (2008), "How China Delivers Development Assistance to Africa". In: China's Development Assistance to Africa. The China Monitor, 28: 4-7.

German, L. A., G. C. Schoneveld, S. Wertz-Kanounnikoff and D. Gumbo (2011), "Chinese Trade and Investment and its Impacts on Forests - A Scoping Study in the Miombo Woodlands", Working Paper 84, Centre for International Forestry Research (CIFOR), Bogro, Indonesia, 1-56.

Hodzi, O., L. Hartwell and N. de Jager (2012), 'Unconditional Aid': Assessing the Impact of China's Development Assistance to Zimbabwe, South African Journal of International Affairs 19 (1): 79-103. https://doi.org/10.1080/10220461.2012.670435

Huse, M.D. and S. L. Muyakwa (2008), "China in Africa: Lending, Policy Space and Governance", Norwegian Campaign for Debt Cancellation and Norwegian Council for Africa, Oslo, Norway.

Igbinoba, E. (2016), "China, Africa's New Colonial Master"? Global Journal of Management and Business Research: B Economics and Commerce, 16 (5): 47-56.

Kleine-Ahlbrandt, S. and A. Small (2008), "China's New Dictatorship Diplomacy. Is Beijing Parting with Pariahs?" in Foreign Affairs, 87 (3) (January/February): 38-56 In. Chris Alden, Daniel Large and Ricardo Soares de Oliveira (eds.), China Returns to Africa. A Rising Power and a Continent Embrace, London, Hurst, 2008.

Kobayashi, T. (2008), "Evolution of China's Aid Policy", in JBICl Working Papers, No. 27 (April), http://jica-ri.jica.go.jp/IFIC_ 
and_JBICI-Studies/jica-ri/english/publication/archives/jbic/ report/working/pdf/wp27_e.pdf.

Kolstad, I. and A. Wiig (2011) 'Better the Devil You Know? Chinese Foreign Direct Investment in Africa', Journal of African Business, 12 (1): 31-50. https://doi.org/10.1080/1536710X.2011.555259

Mandondo, A. and German, L. (2011), "Customary Rights and Societal Stakes of Large-scale Tobacco Cultivation in Malawi", Paper Presented at the Biannual Meetings of the International Association for the Study of the Commons. Hyderabad, India, 10-14 January.

Milledge, S., I. Gelvas and A. Ahrends (2007), "Forestry, Governance and National Development: Lessons Learned from a Logging Boom in Southern Tanzania", TRAFFIC, Tanzania Ministry of Forestry and Tourism and Tanzania Development Partners Group, Dar es Salaam, Tanzania.

Murray, C. (2013), "China to Deploy "Security Force" to UN Peacekeeping Operation in Mall", US-China Economic and Security Review Commission Staff Research Backgrounder, 9 July 2013, http:// www.uscc.gov/sites/default/files/ Research/Backgrounder_China\%20to\%20Deply\%20Security $\% 20$ Force $\% 20$ to $\% 20 \mathrm{UN} \% 20$ Peacekeeping $\% 200$ peration $\%$ 20in\%20Mali_0.pdf.

Niquet, V. (2006), "La stratégie africaine de la Chine", in Politique étrangère, 71 (2), (Summer 2006): 365, https://www.cairn. info/revue-politique-etrangere-2006-2-page-361.htm.
Ojakorotu, V. and R. Kamidza (2018), "Look East Policy: The Case of Zimbabwe-China Political and Economic Relations Since 2000", India Quarterly, SAGE Publications, 74 (1): 17-41. https://doi.org/10.1177/09749284177449642

Rotberg, R.I. (2008), "China into Africa: Trade, Aid and Influence", World Peace Foundation, Cambridge, UK.

SIPRI, SIPRI Yearbook 2015, Oxford, Oxford University Press, 2015.

Stahl, A. K. (2016), "China's Relations with Sub-Saharan Africa”, IAI Working Paper 16 (22 September): 1-29.

Stahl, A. K. (2011), "Contrasting Rhetoric and Converging Security Interests of the European Union and China in Africa", Journal of Current Chinese Affairs, 40 (4): 159, http://journals.sub. unihamburg.de/giga/jcca/article/view/483.

Sun, Y. (2014), "Africa in Chin's Foreign Policy", John L. Thornton China Centre and Africa Growth Initiative, Brookings, (April): $1-45$.

The World Investment Report (2013), UNCTAD, New York and Geneva: United Nations.

Tjønneland, E. N., B. Brandtzæg, A.. Kolås and G. le Pere (2006), "China in Africa - Implications for Norwegian Foreign and Development Policies", Chr. Michelsen Institute (CMI) Report 15: 1-62.

Received on 08-11-2018

Accepted on 11-12-2018

Published on 01-02-2019

DOI: https://doi.org/10.6000/1929-7092.2019.08.09

() 2019 Ojakorotu and Dan-Woniowei; Licensee Lifescience Global.

This is an open access article licensed under the terms of the Creative Commons Attribution Non-Commercial License (http://creativecommons.org/licenses/by-nc/3.0/) which permits unrestricted, non-commercial use, distribution and reproduction in any medium, provided the work is properly cited. 